\title{
Japanese Vocabulary Acquisition by Learners in Three Contexts
}

\author{
Da n P. Dewey \\ University of Pittsburgh
}

This study is an investigation of the development of vocabulary knowledge during study abroad (SA), intensive domestic immersion (IM) and academicyear formal classroom (AY) learning. Freed (1999) has emphasized the importance of knowing how stateside IM and AY experiences compare with SA and of determining the specific shared and unique linguistic benefits of each of these contexts. While few in number, comparisons between these contexts have been made (e.g., DeKeyser, 1986; Dewey, 2004; Freed, 1995b; Freed, Segalowitz \& Dewey, 2004; Lafford, 1995; Milton \& Meara, 1995). Only one study was found (Freed et al., 2004) comparing all three contexts (SA, IM and AY).

One specific linguistic feature explored by researchers comparing SA and stateside learning is vocabulary development (Collentine, 2004; DeKeyser, 1986; Dewey, 2002, 2004; Laufer \& Paribakht, 1998; Milton \& Meara, 1995). Dewey (2004) found that learners of Japanese in Japan made significant gains on one measure of vocabulary knowledge over a semester abroad, but these gains were matched by their counterparts at home in an IM setting. Milton and Meara (1995) reported that ESL students in Britain (from Germany, Spain, Italy and France) acquired English vocabulary five times faster than AY learners. DeKeyser (1986) explored the development of a range of linguistic abilities of Spanish learners and found that vocabulary growth was the one noteworthy difference in linguistic development between American students living in Spain and their fellow students at home. Collentine's (2004) study produced less clear-cut results. In a comparative analysis of oral interviews conducted prior to and following a semester of study at home (AY) or abroad, he found that AY learners did very well overall in comparison with SA participants in terms of showing evidence of acquisition of new words over the study period, but that SA participants produced more unique words than AY learners in their post-study speech samples simply by virtue of being able to speak more fluently (i.e., produce more words per minute). Freed, So and Lazar (2003) employed a number of measures to analyze vocabulary use in written French essays and found no significant differences in terms of gain between learners who went abroad and learners who stayed at home. To summarize, while 
much of the evidence suggests that SA participants tend to out-gain AY learners in vocabulary acquisition during comparable periods of study, there is not always a clear advantage for SA participants in this area (cf. Collentine, 2004 and Freed et al., 2003). Where SA participants have made greater gains than at-home learners, this advantage has been regularly attributed to the availability of rich linguistic input in the overseas setting.

The vocabulary and context research mentioned above was conducted mainly in European languages. Of these studies, just two (Laufer and Paribakht 1998; Milton and Meara 1995) have focused solely on the development of vocabulary knowledge. Due to the multiple foci of most of these studies, only limited vocabulary-related data was typically collected. Laufer and Paribakht (1998) showed the potential of multiple measures in their study, using three distinct measures of vocabulary knowledge to find that the gap between passive and active vocabulary knowledge was significantly larger for ESL SA participants than for their counterparts at home (i.e., they were able to recognize substantially more words than they could produce). The use of a single measure would not have highlighted differences in this way. Collentine (2004), Collentine and Freed (2004) and Dewey (2002, 2004) have suggested the use of multiple and novel measures of language development in the SA and IM contexts, particularly given the failure of some assessments to capture growth for advanced learners during study abroad. Ceiling effects and test biases are two of the most commonly cited reasons for this failure (Brecht, Davidson \& Ginsberg, 1995; Freed, 1995a, 1998).

This study was a response to the call for additional comparisons between language learning abroad and language learning at home. Its focus was the growth of vocabulary knowledge in Japanese-a language where little SA research has been conducted to date. Unlike most studies addressing vocabulary development (including the Dewey, 2004 Japanese study), it was centered strictly on vocabulary acquisition. Following the example of one of the most insightful comparative studies of vocabulary learning abroad and at home to date (Laufer \& Paribakht, 1998), it included multiple measures of vocabulary knowledge to assess possible subtle differences in vocabulary acquisition between the SA, IM and AY settings.

The first research question to be addressed in this study was, "Are there differences in terms of vocabulary development between learners in SA, IM and AY settings?" Although differences in language acquisition are of interest by themselves, it is also important to come to a better understanding of each of the settings where acquisition occurs and of the connections between students' 
contact with language in these settings (both in and out of class) and their language acquisition (Collentine \& Freed, 2004; Dewey, 2002, 2004; Freed, 1993; Freed, 1999; Freed et al., 2004b). As Freed and her colleagues (2004b) have pointed out, "it is not the context per se that promotes various types of learning but rather, ... the nature of the interactions, the quality of the experiences, and the efforts made to use the L2 that render one context superior to another with respect to language gain." (p. 298). The second question, focusing on the nature of interactions and efforts to use the second language was, "Is language contact correlated with vocabulary acquisition in the SA, IM and AY settings?" Language contact was defined as amount and type of language study and use both in and out of the classroom.

\section{The Study \\ Participants}

Fifty-six native speakers of English learning Japanese as a second language (twenty-seven male and twenty-nine female) participated in the study. The majority of the learners (75.0\%) scored at the Intermediate-Low, Mid or High levels on the ACTFL Oral Proficiency Interview. Learners were volunteers located in one of three settings: study abroad (SA) at the Institute for International Education of Students (IES) Study Abroad Center in Tokyo, Japan $(n=20)$, intensive domestic immersion (IM) at the Middlebury College Japanese Language School in Middlebury, Vermont $(n=14)$, and formal academicyear (AY) classrooms at one of four midwestern universities in the United States $(n=22)$. All participants had studied Japanese between two and three years at the university level. Fifty-eight percent of the participants had never learned another language. The remainder had experience learning only Indo-European languages. Participants in each of the programs were similar in terms of the diversity of their prior Japanese language learning experience. ${ }^{1}$ Testing was conducted prior to and following approximately eleven weeks (196 classroom hours) of instruction in the SA setting, nine weeks (198 classroom hours) in IM and thirteen weeks ( 55 classroom hours) in AY. Total number of hours of instruction in each context was taken into consideration in the data analyses (see later description).

During two or more weeks of classroom observations in each of the contexts, the author found no noteworthy differences in instructional approaches. In all three contexts, classroom instruction included a variety of reading, writing, listening and speaking practice. Video and audio materials were used in each setting, but only a small portion of the instructional time was devoted to 
these materials (approximately 10-20\% of class time). Approximately $25 \%$ of class time was spent reading authentic written materials (newspapers, magazines, short stories, etc.) in all contexts. Materials were often read aloud and meaning and grammatical constructs clarified in Japanese, and at least one-third of the classroom time was spent discussing other aspects of the text (readers' opinions, parallels to other events or literature, etc.). In all three contexts, students were typically given vocabulary lists for spoken or written classroom materials. Written vocabulary quizzes occurred regularly in all three contexts. One clear difference between the contexts was that IM students were required to submit for grading and feedback more written assignments (one essay per week, several email messages, and four or more practice handwritten memos over the course of the summer) than their AY and SA peers. IM participants also read slightly more literary passages in proportion to other readings than their counterparts.

SA participants lived in the homes of host families, where they were expected to eat breakfast and dinner every day. They were allowed to use English freely at any time outside of class. IM learners lived in dormitories with other speakers of Japanese and were pledged to use only Japanese at all times. They also ate meals in a cafeteria for Japanese speakers only and participated in a broad range of extracurricular activities in Japanese. AY students lived in English speaking settings typical of college students in the U.S. and had few opportunities to use Japanese outside of class.

\section{Methods and Procedures}

SA and IM researchers (Collentine, 2004; Dewey, 2004; Freed, 1995a; Lapkin, Hart \& Swain, 1995) have suggested the need for variety and creativity in terms of measures used to assess linguistic gains made by learners in these two contexts. Previously used measures have suffered from ceiling effects and other problems such as gender bias (Brecht et al., 1995). To reduce the chances of such problems and to produce a more complete picture of vocabulary growth, three measures were used in this study: a Vocabulary Matching Test, a Japanese version of the Vocabulary Knowledge Scale (Paribakht \& Wesche, 1993), and the Japanese Situational Vocabulary Test (Author, 2005).

The Vocabulary Matching Test (a paper and pencil test) was given to assess a relatively low level of receptive knowledge — the ability to match a word with its definition. The format was chosen because learners in all three settings were familiar with it and had regular experience with similar matching activities in their classroom settings. Words were given in sets of six with three possible definitions. Learners had to select the matching definition for three 
of the six words. The test consisted of 150 possible correct word-definition combinations. Words included in the test were selected based on how frequently they occur in written Japanese texts. ${ }^{2}$ This was done in order to allow for later analyses of test results based on word frequency. Thirty words were selected from each of the following bands: 500 or less (the 500 most frequently occurring words), 501-1000 (the next 500 most frequent words), 1001-1500, 1501-2000, and 2001-4000. The broader 2001-4000 range was included to determine how learners would perform on relatively infrequent words. Words were written in Japanese script as they would normally be printed for native speakers and definitions were given in English rather than Japanese. ${ }^{3}$ Learners were given credit for an item if they matched it with the correct definition (regardless of their accuracy for the other definitions in the set).

The Vocabulary Knowledge Scale was included to assess depth of vocabulary knowledge, providing a picture of a learner's ability to recognize words, produce definitions, and use words in complete sentences. The Vocabulary Knowledge Scale allowed learners to produce simple disconnected sentences, a task that proved to be more do-able for these learners in a short period of testing than producing essays or other extended texts. ${ }^{4}$ Given the complexity of the Japanese writing system, learners were allowed to write sentences in Romanized Japanese or to use Japanese syllabaries to represent words instead of using the more complex Chinese characters (kanji). Since the Vocabulary Knowledge Scale is typically used to determine the effects of instruction on vocabulary development, words that are included are usually selected from course materials. Given the difficulties of finding vocabulary items taught in all three instructional contexts, rather than course materials, words were also selected from a word frequency list for this measure, with the assumption that learners would have regular exposure to more frequent words over the course of their studies. Two-thirds of the vocabulary (thirty-two items) were taken from the 1,000-band (1,000 most frequently occurring Japanese words) and one-third (sixteen items per test) from the 2,000-band (the next 1,000 most frequent set of words).

Vocabulary Knowledge Scale items were scored in accordance with the procedure outlined in Wesche and Paribakht (1993). The number of words falling into each scale category for each individual was also recorded for later detailed analyses to determine patterns within the test related to depth of word knowledge.

The Situational Vocabulary Test (SVT) focused on a specific set of vocabulary that is useful for functioning in everyday situations in Japan (e.g., words used on signs, train schedules, and menus). While one might argue that this test is biased in favor of the study abroad group due to that group's 
regular encounters with this vocabulary, this argument explains precisely why this measure was selected: determine whether these SA participants are able to acquire these vocabulary better than their counterparts at home as a result of this extensive exposure. Collentine (2004) and Dewey (2004) have argued that assessments used in SA research ought to focus on areas where benefits are likely in order to determine whether those benefits do exist and to assess their exact nature.

In the Situational Vocabulary Test, to give learners some context for each word, a location where a word might typically appear was shown prior to the actual word and an English definition was then requested. ${ }^{5}$ This test was given by computer and included fifty words selected and displayed in random order by computer. Learners were given full credit if their English definitions matched the context-appropriate definitions. No partial credit was given, even in cases where a definition may have matched in another context but was not appropriate for the context given.

The three groups of learners were roughly comparable in terms of initial vocabulary knowledge. Univariate ANOVA results showed no significant differences between groups for pre-test results on the Vocabulary Matching Test $(\mathrm{p}=.480)$, the Vocabulary Knowledge Scale $(\mathrm{p}=.602)$ and the Situational Vocabulary Test $(\mathrm{p}=.838)$.

Patterns of language contact and use in each of these three settings were assessed in three ways. First, the Language Contact Profile (Freed, Dewey, Segalowitz \& Halter, 2004a) was given to all participants prior to and following the study period (Pre-Test and Post-Test versions, respectively). Second, following instructions used in O'Donnell's (2004) study abroad diary research, students were asked to write regular diary entries each week regarding their language use. Finally, learners were informally interviewed regarding their language use at the end of the study. Information on language contact gathered through these three methods will not be reported in detail here. Rather, small portions of the data will be used where appropriate to explain vocabulary acquisition in the three contexts. A more detailed study of this data on language contact in these three contexts is reported elsewhere (Author, 2006).

\section{Analyses}

To assess whether differences between the SA, AY and IM groups were significant, three analyses of covariance (ANCOVAs) were conducted, with group as the primary independent variable and results from each vocabulary measure (Vocabulary Matching Test, Vocabulary Knowledge Scale and Situ- 
ational Vocabulary Test) as the single dependent variable in the three separate ANCOVAs. For each ANCOVA, pre-study scores were used as covariates to control for initial vocabulary knowledge.

Following the comparison of gains on the three measures, detailed response analyses were conducted for two of the measures. For the Vocabulary Knowledge Scale, analyses were based on increases in the number of words learners identified as being familiar but unable to define, words they were able to correctly define but not use in a sentence, and words they were able to define and use correctly in a sentence. While Vocabulary Knowledge Scale raw scores have been used in other studies, as Schmitt (2000) and Schmitt and McCarthy (1997) have pointed out, combining results from each of the categories to form one whole score can be problematic because it confounds the various levels of vocabulary knowledge, making it possible for learners to achieve the same score via different types of knowledge. Separate analyses by category is a means of addressing this concern.

For the Vocabulary Matching Test, analyses were based on word frequency bands (i.e., results for less frequent words were compared with results for more frequent words). A series of multivariate analyses of covariance (MANCOVAs) were conducted to assess possible relationships between contexts and response patterns in Vocabulary Knowledge Scale and the Matching Test. Again, in each case vocabulary knowledge at pre-test was used as a covariate to control for initial knowledge.

Finally, correlational and qualitative analyses were performed to assess connections between language contact (as measured by the Language Contact Profile, journal entries and interviews) and vocabulary development in the three contexts. This was done to explore possible explanations for differences in vocabulary development both between and within contexts.

\section{Results}

Table 1 displays group post-test means (adjusted for initial proficiency) for each of the three vocabulary measures. ANCOVA results for the Vocabulary Matching Test indicated that, after adjusting for initial vocabulary knowledge, there were significant differences between groups on post-test scores, $\mathrm{F}(2,52)=4.49, \mathrm{p}=.016$. Post - hoc analyses showed that the SA and IM groups out-gained the AY group, and that there were no significant differences between the SA and IM groups on this measure ( $\mathrm{p}<.05)$. In short, SA and IM learners' abilities to match definitions on this test developed more during the study period than AY learners' abilities. 
Table 1: $\quad$ Post-Test Estimated Marginal Means (standard error in parentheses)

\begin{tabular}{|l|l|l|l|l|l|l|}
\hline Group & \multicolumn{2}{|c|}{$\begin{array}{c}\text { Situational } \\
\text { Vocabulary Test }\end{array}$} & \multicolumn{2}{c|}{$\begin{array}{c}\text { Vocabulary } \\
\text { Knowledge Scale }\end{array}$} & \multicolumn{2}{c|}{$\begin{array}{c}\text { Vocabulary } \\
\text { Matching Test }\end{array}$} \\
\hline SA $(\mathrm{N}=20)$ & 15.7 & $(.89)$ & 115.6 & $(2.65)$ & 23.1 & $(.93)$ \\
\hline $\mathrm{IM}(\mathrm{N}=14)$ & 11.5 & $(1.06)$ & 116.0 & $(3.15)$ & 24.1 & $(1.08)$ \\
\hline $\mathrm{AY}(\mathrm{N}=22)$ & 10.7 & $(.85)$ & 99.9 & $(2.52)$ & 20.2 & $(.87)$ \\
\hline
\end{tabular}

There were also significant differences between groups for the Vocabulary Knowledge Scale, F(2,52)=11.89, p<.001. Again, the IM and SA groups out-gained the AY group $(\mathrm{p}<.05)$. These learners showed greater evidence of vocabulary development on this measure aimed at depth of vocabulary knowledge than the AY learners.

Significant differences between groups were found again for the Situational Vocabulary Test, $\mathrm{F}(2,52)=8.91, \mathrm{p}<.001$. SA participants out-gained both IM and AY participants $(\mathrm{p}<.05)$. They were more able to define words typically encountered in everyday situations in Japan than their at-home counterparts.

\section{Results by Category and Frequency}

For the Vocabulary Knowledge Scale, MANCOVA results indicated a significant overall difference between the three contexts in terms of patterns in increases in the number of words fitting into the following categories: familiar but unable to define, able to define, and able to use in a sentence-Pillai's trace $=.657, \mathrm{~F}(6$, $102)=.8 .31, \mathrm{p}<.001$, multivariate $\eta^{2}=.33$. Follow-up univariate ANCOVAs indicated significant differences between contexts for each category-familiar, can define, and can use in a sentence, $\mathrm{F}(2,52)=14.17, \mathrm{p}<.001, \mathrm{~F}(2,52)=8.68, \mathrm{p}<.001$, $\mathrm{F}(2,52)=7.29, \mathrm{p}=.002$, respectively. Post hoc tests showed that SA learners became familiar with (but were unable to define) more words than both AY and IM learners $(\mathrm{p}=.001 \text { and } \mathrm{p}=.027 \text {, respectively })^{6}$. IM learners gained more in terms of ability to define words (but still not use them in a sentence) than AY participants ( $\mathrm{p}=.041$ and $\mathrm{p}=.009$, respectively). IM learners grew more in their ability to use words in sentences than their counterparts in the SA and AY settings $(p=.035, p=.008$, respectively) Table 2 shows the mean gains in each category for each context.

Table 2: Increase in number of words between pre- and post-testing by type of knowledge for the Vocabulary Knowledge Scale

\begin{tabular}{|l|l|l|l|l|l|l|}
\hline & \multicolumn{2}{|l|}{$\begin{array}{l}\text { Familiar but } \\
\text { Can't Define }\end{array}$} & \multicolumn{2}{l|}{$\begin{array}{l}\text { Can Define but } \\
\text { Not Use in Sentence }\end{array}$} & \multicolumn{2}{l|}{$\begin{array}{l}\text { Can Define and } \\
\text { Use in Sentence }\end{array}$} \\
\hline SA & 9.6 & $(7.94)$ & 5.2 & $(3.12)$ & 1.3 & $(1.59)$ \\
\hline IM & 4.2 & $(2.83)$ & 6.1 & $(2.80)$ & 2.8 & $(1.97)$ \\
\hline AY & 1.5 & $(2.32)$ & 3.0 & $(2.77)$ & 1.0 & $(1.51)$ \\
\hline
\end{tabular}


For the Vocabulary Matching Test, MANCOVA results for gains according to frequency of words used in the Vocabulary Matching Test indicated overall significant differences between the three contexts in terms of less frequent words (not among the 1,500 most frequent Japanese words) and more frequent words (among the 1,500 most frequent words), Wilks' $\Lambda=.771$, $\mathrm{F}(4,102)=3.55, \mathrm{p}=.009$, multivariate $\eta 2=.122$ (gains are displayed in Table 3). Univariate ANCOVAs showed significant differences depending on context only for low-frequency (above the 1,500 level) words, $\mathrm{F}(2,52)=1.51, \mathrm{p}=.006$. IM participants gained more in terms of accuracy for the less frequent words over the study period than did the AY or SA participants $(\mathrm{p}<.05)$. Table 3 shows the results for each context by frequency level.

Table 3: Increase in number of words by frequency for the Vocabulary Matching Test between pre- and post-testing

\begin{tabular}{|l|l|l|l|l|}
\hline \multicolumn{3}{|l|}{ More Frequent } & \multicolumn{3}{l|}{ Less Frequent } \\
\hline SA & 4.8 & $(2.95)$ & 1.8 & $(2.12)$ \\
\hline IM & 4.1 & $(3.42)$ & 4.1 & $(2.46)$ \\
\hline AY & 3.5 & $(3.02)$ & 2.2 & $(1.87)$ \\
\hline
\end{tabular}

\section{Language Contact}

Tables 4, 5 and 6 include correlations between the three measures of vocabulary and amount of speaking, listening, reading and writing reported in the SA, IM and AY contexts, respectively. All other (more specific) types of language contact that were found to be significantly correlated with any of the vocabulary measures for the three contexts are also included in the tables.

For SA participants, a moderate significant correlation was found between amount of time spent speaking Japanese with others and results on the Situational Vocabulary Test. Total amount of time spent writing in Japanese correlated moderately and significantly with results on the Vocabulary Knowledge Scale. In terms of more specific types of language contact, amount of time spent speaking with Japanese friends was significantly and positively correlated with two of the three vocabulary measures; time spent speaking with host families was significantly correlated with one vocabulary measure. Reading email or surfing the Web in English correlated significantly and negatively with Situational Vocabulary Test results. Similarly, amount of time spent reading email or surfing the Internet in Japanese correlated significantly and negatively with Vocabulary Knowledge Scale results. Although not all significant, correlations between reading email and surfing the Internet both in English and in Japanese correlated negatively with all three vocabulary measures. 


\begin{tabular}{|c|c|c|c|}
\hline 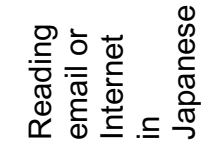 & స్ & 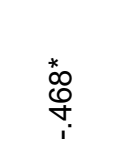 & $\underset{i}{\check{n}}$ \\
\hline 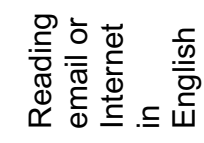 & $\begin{array}{l}\stackrel{\infty}{\infty} \\
\stackrel{\infty}{\digamma}\end{array}$ & ?़ & $\stackrel{\text { L }}{\stackrel{\text { L }}{+}}$ \\
\hline 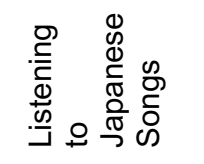 & ষ্ & $\begin{array}{l}\text { ै } \\
\stackrel{*}{0}\end{array}$ & 今. \\
\hline 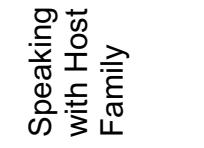 & $\bar{\emptyset}$ & $\frac{N}{\underset{v}{v}}$ & $\begin{array}{l}* \\
\stackrel{9}{+}\end{array}$ \\
\hline 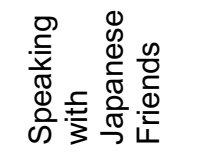 & 고 & 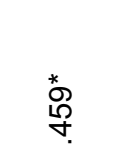 & $\frac{\stackrel{*}{*}}{\stackrel{*}{0}}$ \\
\hline 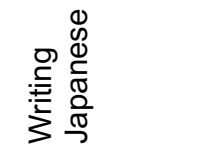 & $\frac{0}{m}$ & $\stackrel{*}{n}$ & $\begin{array}{l}\text { L } \\
\infty \\
\text { లి }\end{array}$ \\
\hline 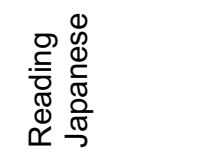 & مَ & 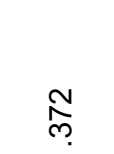 & ले \\
\hline 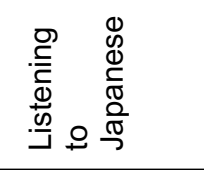 & চా & 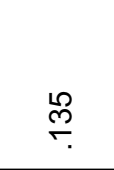 & ণָ \\
\hline 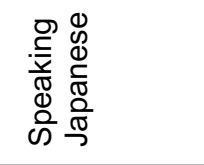 & $\stackrel{\bullet}{N}$ & $\begin{array}{l}\text { م } \\
\text { లి }\end{array}$ & $\stackrel{\text { م }}{\stackrel{*}{+}}$ \\
\hline & 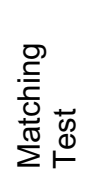 & 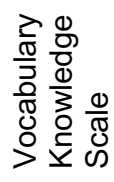 & 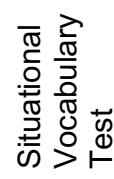 \\
\hline
\end{tabular}


Frontiers: The Interdisciplinary Journal of Study Abroad

\begin{tabular}{|c|c|c|c|}
\hline 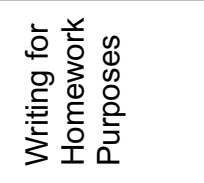 & $\hat{\mathscr{\rho}}$ & 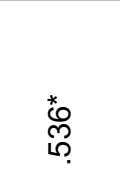 & $\begin{array}{l}\stackrel{*}{n} \\
\stackrel{n}{n}\end{array}$ \\
\hline 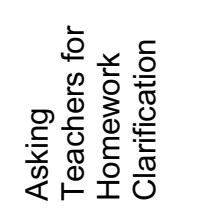 & స్లి & ষ & \begin{tabular}{l}
$*$ \\
$\stackrel{*}{0}$ \\
\multirow{L}{*}{}
\end{tabular} \\
\hline 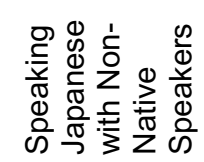 & $\bar{\sim}$ & $\stackrel{*}{\frac{*}{\sigma}}$ & ণ্ণ \\
\hline 焉离 & $\frac{\curvearrowright}{\sigma}$ & 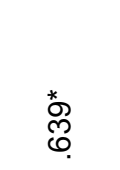 & 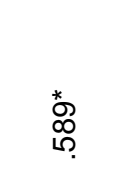 \\
\hline 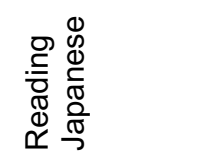 & $\begin{array}{l}\infty \\
\stackrel{p}{p} \\
\text {. }\end{array}$ & 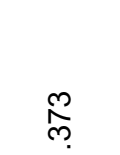 & 尺্ \\
\hline 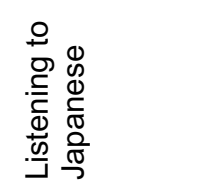 & $\stackrel{\leftrightarrow}{\sim}$ & శ్రి & ஜ़ \\
\hline 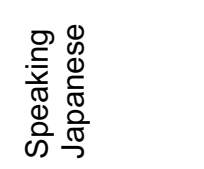 & $\begin{array}{l}\text { \$ } \\
\text { N̦ }\end{array}$ & $\stackrel{\mathscr{O}}{\stackrel{\infty}{+}}$ & ஜ্ণ \\
\hline & 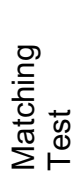 & 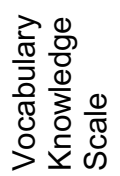 & 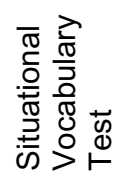 \\
\hline
\end{tabular}


D a n P. D e w e y

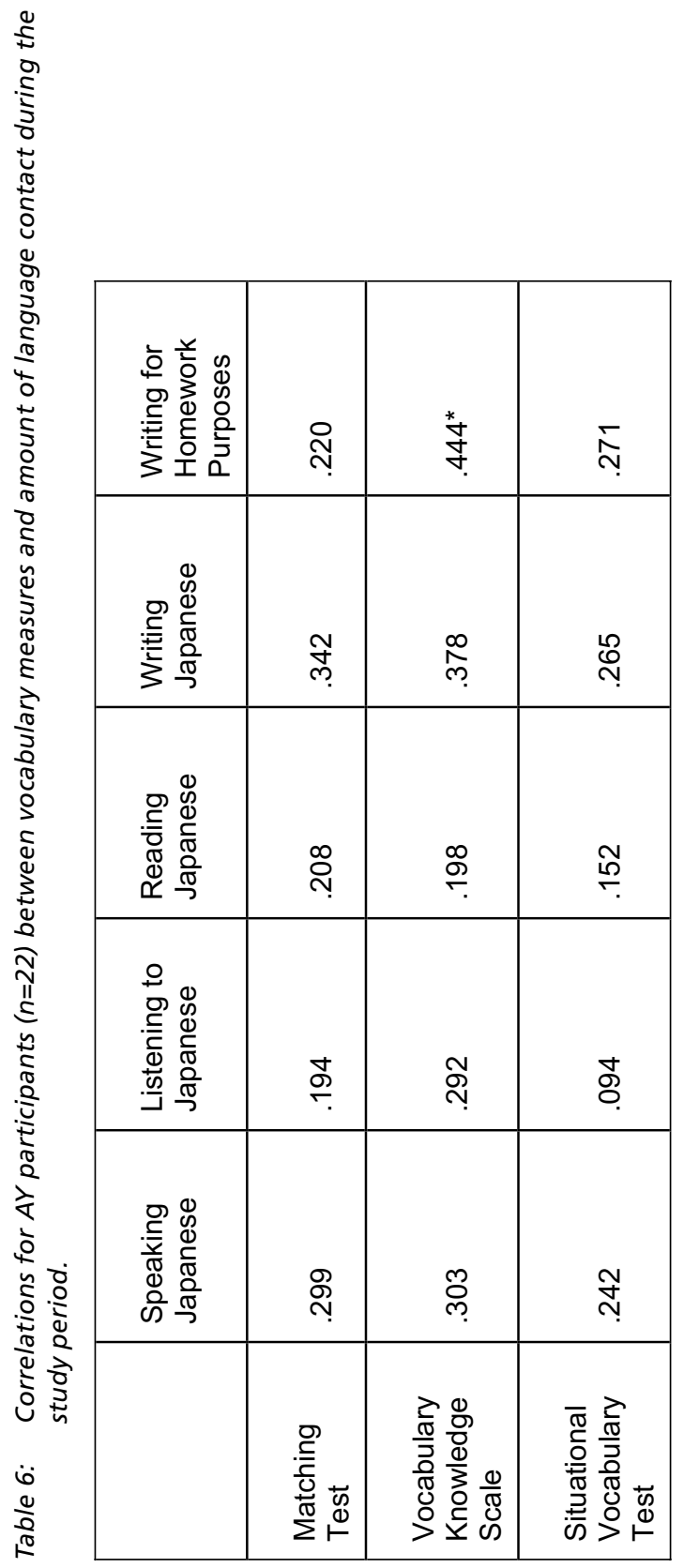


For IM participants, there was a significant and relatively high correlation between time spent writing in Japanese and Vocabulary Knowledge Scale results. Similarly, amount of time spent writing for homework purposes correlated significantly both with Vocabulary Knowledge Scale and with Situational Vocabulary Test results. Amount of time spent speaking Japanese with non-native speakers correlated significantly and to a moderately high degree with Vocabulary Knowledge Scale results. Amount of time spent asking teachers for homework clarification was significantly correlated with Situational Vocabulary Test results.

For the AY group, a significant and moderate correlation was found between amount of time spent writing for homework purposes and results from the Vocabulary Knowledge Scale.

\section{Discussion}

Results showed differences between contexts in terms of vocabulary acquisition. Furthermore, significant correlations were found between language contact and vocabulary acquisition in the SA, IM and AY settings.

\section{Study Abroad}

SA participants outperformed AY learners on all three measures of vocabulary knowledge. This finding matches previous research in European languages (DeKeyser, 1986; Laufer \& Paribakht, 1998; Meara, 1994) and provides further evidence that SA tends to facilitate vocabulary acquisition more than AY learning. Detailed analyses of Vocabulary Knowledge Scale results showed that SA participants became familiar with (but still unable to define) more words than both the IM and AY groups.

One variable with potential to explain overall differences in vocabulary acquisition between $S A$ and $A Y$ is number of hours of classroom instruction. As reported earlier, SA participants received nearly four times as many classroom hours of instruction during their study periods than AY learners. In spite of differences in number of classroom hours, these settings were compared to determine the benefits of studying abroad for a semester over staying at home in an academic-year setting for the same semester period. Doing so also allowed for comparison with previous studies that have taken a similar approach (Collentine, 2004; DeKeyser, 1986; Freed, 1995b; O’Donnell, 2004; Segalowitz \& Freed, 2004). It might be beneficial in the future to compare the linguistic impact of AY learning in terms of number of classroom hours rather than length of study (i.e., semester, academic year, etc.) to assess the value of massed versus distributed learning. 
Another variable that might contribute to greater vocabulary acquisition in SA over AY is more extensive exposure to language outside of the classroom. Data from this study reported elsewhere (Author, 2006) indicated that SA participants spoke, read, wrote and listened to more Japanese over the semester period than their counterparts at home. ${ }^{7}$ Evidence of the possible influence of out-of-class language exposure on vocabulary acquisition was seen in correlation data reported earlier in this article. Time spent writing was significantly correlated with vocabulary knowledge scale results and time spent speaking Japanese with Situational Vocabulary Test and with passive familiarity with words on the Vocabulary Knowledge Scale. A study in French (Freed, Segalowitz \& Dewey, 2004) found significant correlations between time spent writing in the target language and measures of second language oral fluency. This writing-fluency connection was attributed to the depth of processing required in the writing process, which likely led to more automatization of production. Furthermore, writing was said to have likely facilitated the memorization of chunks of lexical items, chunks that could easily be repeated with fluency in spoken form. Depth of processing through writing likely facilitated greater acquisition of vocabulary in the current Japanese study as well.

Some of the highest correlations for the SA data were between time spent speaking with Japanese friends and Vocabulary Knowledge Scale and Situational Vocabulary Test results. While conversation time with home-stay families was correlated moderately with these measures, time spent with other friends was correlated at a higher level. The more a person spoke with friends in Japanese, the more likely she was to show passive knowledge of vocabulary (i.e., to identify words as being familiar) and to acquire situational/functional vocabulary. This study's finding of greater correlations with vocabulary knowledge development for time spent speaking with friends outside of the homestay setting than for time spent speaking in the homestay setting supports the idea that homestays may not provide interactions as linguistically rich as other social settings (cf. Frank, 1997; Pellegrino, 1997; Pellegrino, 1998; Rivers, 1998; Wilkinson, 1996, 1998a, 1998b).

Relationships were found between time spent using e-mail and the Internet, both in Japanese and English, and measures of vocabulary development. Although only two correlations were significant (time spent reading email or web pages in Japanese and Vocabulary Knowledge Scale and time spent reading email or web pages in English and Situational Vocabulary Test), all were negative. The more a person used email or the Internet, the less likely he was to make gains on the vocabulary measures. Language contact data supported this finding. The same 
three learners who scored poorly on the Situational Vocabulary Test also reported spending over three hours a day more on the Internet than the average student in their group. As one student noted, "I can't seem to make friends here in Japan, so I spend a lot of time with my friends on-line." In short, as Freed and her colleagues have also pointed out (Freed et al., 2004b), interaction and output appear to play a critical role in language acquisition during study abroad.

\section{Intensive Domestic Immersion}

The IM group scored more than AY learners on all measures (though differences between the two on the Situational Vocabulary Test were not significant). IM students were also more able to produce words in complete sentences on the Vocabulary Knowledge Scale than both SA and AY participants. Finally, they showed greater knowledge of less frequent words than both SA and AY participants.

Again, hours of classroom language learning time and exposure to language outside of class are important factors with explanatory power. IM participants also had nearly four times as many classroom hours as AY participants. Furthermore, they reported having approximately eight times as much exposure to Japanese out of class as AY students (Author, 2006). Differences between IM and SA contexts cannot be explained by classroom time, which was nearly identical. They can, however, be explained largely by differences in language contact. IM participants reported engaging in an average of 83.6 more hours per week of productive language use (speaking and writing) than their SA counterparts. This productive language use likely led to greater ability to create sentences using the words in Japanese for IM learners than for SA. Freed, Segalowitz \& Dewey (2004) similarly found that amount of time spent writing in the target language (French) predicted how well learners' spoken fluency developed. Those who wrote more tended to speak with fewer hesitations and use fewer fillers than those who wrote less.

Correlation data supported a connection between writing and speaking and vocabulary acquisition during IM. Significant and moderately strong correlations were found between time spent writing Japanese and Situational Vocabulary Test results and between time writing and Vocabulary Knowledge Scale aggregated and sentence-level scores. Time spent speaking with nonnative speakers was also correlated with Vocabulary Knowledge Scale aggregated and sentence-production results. This final finding indicates the potential value of speaking a second language even with non-native speakers.

The IM group made greater gains on less frequent words than the other two groups. Informal analyses of texts used in the SA, IM and AY settings 
showed a slightly heavier emphasis on literature in the IM context than in SA or AY. Literary passages used as course readings tended to contain words at the 3,000-level or above more often than other materials such as newspaper or magazine articles. A more careful analysis of all materials used in the class and in the other contexts would be necessary for definitive conclusions regarding this point. If there is a connection between frequency of words in instructional materials and acquisition of less frequent words, then this finding is similar to Dewey's (2004) finding that learners were more subject to the influence of their instructors in the IM setting than the SA setting. Dewey attributed this influence to the controlled setting, which contrasts with the very open SA setting, where learners can engage in countless activities outside of the classroom.

\section{Academic-Year Setting}

AY learners tended to gain less overall in terms of vocabulary acquisition than IM and SA participants. It could be that if learners in this setting were tracked over a longer period during which they were given hours of instruction comparable to the number given during the SA semester and the IM summer, similar results could result. However, there are some indications that massed intensive instruction may lead to better results than distributed instruction (Collins, Halter, Lightbown \& Spada, 1999; B. Rifkin, 2005). Collins, Halter, Lightbown and Spada found that young learners (ages 12-13) given massed intensive instruction outperformed comparable learners with the same number of hours of language instruction distributed over a longer period of time. Rifkin used background data and statistical models to assess differences in outcomes for massed intensive immersion and distributed academic-year classroom instruction and determined that the statistical models predicted greater outcomes for intensive immersion participants than for those in distributed academic-year classroom instruction. While these studies indicate some possible patterns, additional research is needed in this area before generalizations can be made. Regardless of the research outcomes, the obvious advantage of massed intensive immersion is that learners are able to acquire more language over shorter periods of time.

In the AY context, amount of time spent writing for homework purposes correlated significantly and mildly with Vocabulary Knowledge Scale aggregate and sentence production results. The more time AY learners spent writing for homework purposes, the higher their score was on the Vocabulary Knowledge Scale. While this was not a high correlation, it is an indication that the role of writing may also be important for L2 language acquisition at home. 


\section{Conclusion}

The research reported here indicates that SA is an effective means of developing vocabulary knowledge. Those who go abroad seem to develop vocabulary most effectively by engaging in the productive activities of writing and speaking in the target language, as opposed to more passive activities, such as reading email and browsing the Internet. In particular, it appears that those who are able to develop friendships and engage in social networks tend to acquire more vocabulary than those who do not. While there may be intervening factors such as motivation and aptitude that connect vocabulary acquisition and socialization (cf. Brecht et al., 1995; Gardner, Masgoret \& Tremblay, 1999; Masgoret \& Gardner, 2003), the connection is at least one worth exploring through further research.

Overall, gains in vocabulary were fairly similar between the SA and IM settings. Dewey $(2002,2004)$ found similar results for reading comprehension and on one measure of vocabulary knowledge. Freed, Segalowitz and Dewey (2004) found that IM learners of French outperformed SA participants on several measures of oral fluency. Rifkin $(2003,2005)$ has suggested that the controlled IM setting allows learners to cope with linguistically complex tasks in an environment with fewer cultural and social obstacles, limiting affective barriers and freeing up more resources for language acquisition. Furthermore, as Rifkin (2005) and Dewey (2002, 2004) have noted, the pledge to use only the target language compels learners to produce language, and this also contributes $^{8}$ to the acquisition process in the controlled IM setting. The connection found in the current study between time spent speaking with non-native speakers in the IM setting and productive vocabulary knowledge draws attention to the importance of understanding better the impact of interacting with non-native speakers on language development in this and other settings, in particular when a language pledge is enforced.

The importance of productive language use (speaking and writing) was highlighted in this study, in particular for overseas learners. This study suggests that there may be benefits to providing writing opportunities for learners in all three settings, and that facilitating language use through the development of relationships outside of the home-stay setting might be useful for study abroad participants. As Batstone (2002) and Segalowitz and Freed (2004) have pointed out, preparing learners with sufficient linguistic skills may be necessary for them to take full advantage of the rich communicative opportunities available in the study abroad setting because this provides learners with the necessary skills and confidence to build these relationships. 


\section{Author's Note}

This research was made possible by grants from the Japan Iron and Steel Federation and Mitsubishi Endowments of the University of Pittsburgh's Asian Studies Center

\section{Notes}

${ }^{1}$ No more than four participants from the same home institution were included in the SA and the IM populations. See Dewey $(2002,2004)$ and Warnick (1996) for descriptions of very similar subjects from the same IM setting. AY participants had a range of learning experiences prior to this researchapproximately half learning Japanese largely through Romanized text and half through Japanese script. These contrasting approaches are typical in Japanese language education (for discussions of these approaches to Japanese language instruction, see Hatasa, 2002; and Matsunaga, 1995). This division between Romized and non-Romanized textbook users mirrored closely the proportions in the SA and IM settings.

2 Word frequency information for this instrument was generated using the Japanese Lexical Database, by the CJK Dictionary Institute (see http:// www.cjk.org/cjk/samples/japsam.htm), produced December, 2001.

3 There are some similarities between the Vocabulary Matching Test and the Nation's Levels Test, but the Matching Test is not comparable to the Levels Test. In this Matching Test, learners match definitions rather than synonyms. Furthermore, vocabulary are listed in Japanese and definitions in English, whereas in Nation's Levels Test, definitions and synonyms are both given in English. Finally, this Matching test has not been subjected to the extensive validation process that the Levels Test has undergone.

${ }^{4}$ Laufer and Paribakht (1998) used the Lexical Frequency Profile, a measure that assesses vocabulary use in essays written by learners, as a measure of productive knowledge in their study. This measure was not practical here.

5 The complete list of categories and words is available from the author.

6 All post-hoc analyses were either Tukey-HSD or Games-Howell, depending on equality of variance, etc.

7 Details on language contact are reported in great detail in Dewey (2006).

8 Swain's $(1995,1998)$ output hypothesis suggests that this would facilitate acquisition. 


\section{References}

Author (2006). Language contact and context. Manuscript submitted for publication. Batstone, R. (2002). Contexts of engagement: A discourse perspective on "intake" and "pushed output". System, 30, 1-14.

Brecht, R. D., Davidson, D. E., \& Ginsberg, R. B. (1995). Predictors of foreign language gain during study abroad. In B. F. Freed (Ed.), Second language acquisition in a study abroad context. (pp. 37-66). Amsterdam, The Netherlands: John Benjamins Publishing Co.

Collentine, J. (2004). The effects of learning contexts on morphosyntactic and lexical development. Studies in Second Language Acquisition, 26, 227-248.

Collentine, J., \& Freed, B. F. (2004). Learning context and its effects on second language acquisition. Studies in Second Language Acquisition, 26, 153-171.

Collins, L., Halter, R. H., Lightbown, P. M., \& Spada, N. (1999). Time and the distribution of time in L2 instruction. TESOL Quarterly, 33, 655-680.

DeKeyser, R. (1986). From learning to acquisition? Foreign language development in a U. S. classroom and during a semester abroad. Unpublished doctoral dissertation, Stanford University.

Dewey, D. P. (2002). The effects of study context on the acquisition of reading by students of Japanese as a second language: A comparison of study-abroad and intensive domestic immersion. Unpublished doctoral dissertation, Carnegie Mellon University, Pittsburgh, PA.

Dewey, D. P. (2004). A comparison of reading development by learners of Japanese in intensive domestic immersion and study abroad contexts. Studies in Second Language Acquisition, 26, 303-327.

Frank, V. (1997, March 22). Potential negative effects of homestay. Paper presented at the Middle Atlantic Conference of the American Association for the Advancement of Slavic Studies, Albany, NY.

Freed, B. (1993). Assessing the Linguistic Impact of Study Abroad: What We Currently Know - What We Need to Learn. Journal of Asian Pacific Communication, 4(4), 151-166.

Freed, B., So, S., \& Lazar, N. A. (2003). Language learning abroad: How do gains in written fluency compare with gains in oral fluency in French as a second language? ADFL Bulletin, 34(3), 34-40.

Freed, B. F. (1995a). Language learning and study abroad. In B. F. Freed (Ed.), Second language acquisition in a study abroad context. (pp. 3-33). Amsterdam, The Netherlands: John Benjamins Publishing Co.

Freed, B. F. (1995b). What makes us think that students who study abroad become fluent? In B. F. Freed (Ed.), Second language acquisition in a study 
abroad context (pp. 123-148). Amsterdam, The Netherlands: John Benjamins Publishing Co, 1995.

Freed, B. F. (1998). An overview of issues and research in language learning in a study abroad setting. Frontiers, IV(Fall), 31-60.

Freed, B. F. (1999). Retrospective Views from the President's Commission on Foreign Language and International Studies and Prospects for the Future. Paper presented at the Study Abroad and Language Learning, The Study of Foreign Languages in the New Century: Retrospective Views from 'The President's Commission on Foreign Languages and International Studies' and Prospects for the Future Symposium, sponsored by the Stanford Language Center and the Institute for International Studies. Stanford, CA: Stanford University.

Freed, B. F., Dewey, D. P., Segalowitz, N., \& Halter, R. (2004a). The Language Contact Profile. Studies in Second Language Acquisition, 26, 349-356.

Freed, B. F., Segalowitz, N., \& Dewey, D. P. (2004b). Context of learning and second language fluency in French: Comparing regular classroom, study abroad, and intensive domestic immersion programs. Studies in Second Language Acquisition, 26, 275-301.

Gardner, R. C., Masgoret, A.-M., \& Tremblay, P. F. (1999). Home background characteristics and second language learning. The Journal of Language and Social Psychology, 18(4), 419-437.

Hatasa, Y. A. (2002). The effects of differential timing in the introduction of Japanese syllabaries on early second language development in Japanese. Modern Language Journal, 86(3), 349-367.

Lafford, B. A. (1995). Getting into, through, and out of a survival situation: A comparison of communicative strategies used by students studying Spanish-abroad and 'at home'. In B. F. Freed (Ed.), Second language acquisition in a study abroad context (pp. 97-121). Amsterdam, The Netherlands: John Benjamins Publishing Co.

Lapkin, S., Hart, D., \& Swain, M. (1995). A Canadian interprovincial exchange: Evaluating the linguistic impact of a three-month stay in Quebec. In B. F. Freed (Ed.), Second language acquisition in a study abroad context (pp. 67-94). Amsterdam, The Netherlands: John Benjamins Co.

Laufer, B., \& Paribakht, T. S. (1998). The relationship between passive and active vocabularies: Effects of language learning context. Language Learning, 48(3), 365-391.

Masgoret, A.-M., \& Gardner, R. C. (2003). Attitudes, motivation and second language learning: A meta-analyses of studies by Gardner and his associates. Language Learning, 53, 123-163. 
Matsunaga, S. (1995). The role of phonological coding in reading kanji: A research report and some pedagogical implications. Honolulu: University of Hawaii Second Language Teaching and Curriculum Center.

Meara, P. (1994). The year abroad and its effects. Language Learning Journal, 10(Sept), 32-38.

Milton, J., \& Meara, P. (1995). How periods abroad affect vocabulary growth in a foreign language. Review of Applied Linguistics, 107-108, 17-34.

O'Donnell, K. (2004). Student perceptions of language learning in two contexts: At bome and study abroad. Unpublished doctoral dissertation, University of Pittsburgh, Pittsburgh, PA.

Paribakht, T. S., \& Wesche, M. (1993). The relationship between reading comprehension and second language development in a comprehension-based ESL program. TESL Canada Journal, 11(1), 9-29.

Pellegrino, V. (1997). Social and psychological factors affecting spontaneous second language use during study abroad. Unpublished Doctoral Dissertation, Bryn Mawr College.

Pellegrino, V. (1998). Student perspectives on language learning in a study abroad context. Frontiers, Fall, 91-120. Frontiers, IV(Fall), 91-120.

Rifkin, B. (2003). Oral proficiency learning outcomes and curricular design. Foreign Language Annals, 36(4), 582-588.

Rifkin, B. (2005). A ceiling effect in traditional classroom foreign language instruction: data from Russian. Modern Language Journal, 89(1), 3-18.

Rivers, W. P. (1998). Is being there Enough? The effects of homestay placements on language gain during study abroad. Foreign Language Annals, 31(4), 492-500.

Segalowitz, N., \& Freed, B. F. (2004). Context, contact and cognition in oral fluency acquisition: Learning Spanish in at home and study abroad contexts. Studies in Second Language Acquisition, 26, 173-199.

Schmitt, N. (2000). Vocabulary in language teaching. Cambridge: Cambridge University Press.

Schmitt, N. \& McCarthy, M. (1997). Vocabulary: Descrption, acquisition and pedagogy. Cambridge: Cambridge University Press.

Warnick, J. P. (1996). A phenomenology of reading performances: Reading Japanese as a foreign language. . Unpublished doctoral dissertation, The Ohio State University, Columbus, $\mathrm{OH}$.

Wilkinson, S. (1996). Foreign language conversation and the study abroad transition: A case study. Dissertation Abstracts International, A: The Humanities and Social Sciences, 57(1), 140-A. 
Wilkinson, S. (1998a). On the nature of immersion during study abroad: Some participant perspectives. Frontiers: The Interdisciplinary Journal of Study Abroad, IV(Fall), 121-138.

Wilkinson, S. (1998b). Study abroad from the participants' perspective: A challenge to common beliefs. Foreign Language Annals, 31(1), 23-39. 